\title{
The effect of sewage discharge on Melarhaphe neritoides (Gastropoda: Littorinidae) population dynamics
}

\author{
JOANA CABRAL-OLIVEIRA ${ }^{1}$, PAULO MARANHÃO ${ }^{1,2}$ and \\ MIGUEL ÂNGELO PARDAL ${ }^{1}$ \\ ${ }^{1}$ IMAR - Institute of Marine Research, Department of Zoology, University of Coimbra, 3004 - 517 Coimbra, Portugal. \\ E-mail address: joanaco@ci.uc.pt \\ ${ }^{2}$ GIRM - Marine Resources Research Group, School of Maritime Technology, Campus 4 , \\ Santuário Na Sra dos Remédios, Apartado 126, 2524 - 909 Peniche, Portugal.
}

\begin{abstract}
SUMMARY: The discharges of sewage effluent treatment plants has a major impact on coastal communities. In our study area (western coast of Portugal) Melarhaphe neritoides (L. 1758) is the dominant high-shore gastropod. Two populations of $M$. neritoides were studied in order to understand the impact of sewage discharges on intertidal communities: one population in an impacted area and the other in a similar but unimpacted area (reference site). Environmental data and abundance, biomass, population structure and annual growth production of $M$. neritoides were estimated in the two areas. The results showed that $M$. neritoides density is higher in the impacted area as a result of massive settlement. The sewage discharge increases the nutrient concentrations in the water, which causes more microalgae to grow on the rocky surfaces. This higher availability of food may promote recruitment. However, we found high mortality in the juveniles in the impacted area, which affected density values on the upper shore levels (where we found the adults) of both areas. Moreover, the adults were bigger in the unimpacted area, which suggests that individuals grow more or live longer in this area.
\end{abstract}

Keywords: Melarhaphe neritoides, abundance, biomass, secondary production, sewage, nutrient enrichment, rocky shore.

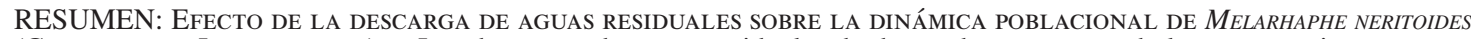
(GASTROPODA: LitTORINIDAE). - Las descargas de aguas residuales de depuradoras son uno de los mayores impactos sobre las comunidades costeras. En nuestra área de estudio (costa oeste de Portugal) Melarhaphe neritoides (L. 1758) es el gasterópodo dominante en la zona supralitoral. Para entender el impacto que estos vertidos tienen sobre las comunidades intermareales, estudiamos dos poblaciones de $M$. neritoides: una en un área contaminada y otra en una zona similar, pero no impactada (zona de referencia). En ambas áreas se registraron datos medioambientales, datos de abundancia y biomasa de $M$. neritoides y se estimó la estructura de las poblaciones y la producción anual. Los resultados muestran una mayor densidad de $M$. neritoides en la zona contaminada, como resultado de una colonización masiva. Las descargas de aguas residuales aumentan la concentración de nutrientes en el agua, provocando un mayor crecimiento de microalgas en la superficie de las rocas, lo que facilita la colonización. Sin embargo, verificamos una elevada mortalidad de juveniles en la zona contaminada que aproximó los valores de la densidad de las poblaciones en las zonas más altas del litoral (donde encontramos los adultos) en ambas zonas. Además, los adultos eran de mayor tamaño en las áreas no contaminadas, lo que sugiere que en esta zona los individuos tienen un mayor crecimiento o viven durante más tiempo.

Palabras clave: Melarhaphe neritoides, abundancia, biomasa, producción secundaria, aguas residuales, enriquecimiento en nutrientes, costa rocosa.

\section{INTRODUCTION}

Organic and nutrient enrichments from domestic wastes have a great impact on marine nearshore ecosystems (Arévalo et al., 2007). There have been several studies on biological assemblages, including plankton, fish and macroalgae, in order to assess the effects of this impact (Bishop et al., 2002; Terlizzi 
et al., 2005; Fraschetti et al., 2006 and references therein). However, there are few papers that describe the response of macrobenthic assemblages living on hard substrata like Gastropoda. Gappa et al. (1990) studied the influence of sewage pollution on a rocky intertidal community from Argentina. In that community the pulmonate limpet Siphonaria lessoni increased its percent cover in transects near the outfall. Tablado and Gappa (2001) referred to the larger sizes and growth rates in the vicinity of sewage effluents observed in Patella vulgata by Fischer-Piette (1948) and in Siphonaria lessoni by Tablado et al. (1994). Bishop et al. (2002) examined the impact of a sewage outfall in Australia on the abundance of intertidal green algae and gastropods at two spatial scales: several hundred metres from the outfall versus several kilometres away (larger spatial scale); and immediately adjacent to the point of discharge versus approximately $50 \mathrm{~m}$ away (smaller spatial scale). On the larger scale Patelloida latistrigata and Siphonaria spp. were more abundant at the impacted area, but on the smaller scale they were less dense. Cellana tramoserica were also less abundant near the discharge but no differences were observed on a larger scale. However, Terlizzi et al. (2005) observed an increase in the number of recruits of some species (Pusillina philippi, Bittium latreilli, $B$. reticulatum) in the polluted area. It seems that the responses of gastropods to sewage pollution are complex, although in most cases the density and growth rate were superior in the polluted areas.

Melarhaphe neritoides typically lives in crevices on rocky shores, which provide protection against wave action, predation and desiccation (Fretter and Manly, 1977; Raffaelli and Hughes, 1978). Crevices increase the local density (Hughes and Roberts, 1981), which suggests $M$. neritoides prefers this habitat. These organisms feed on microalgae and lichens on the rock surface (Stafford and Davies, 2005) and are able to resist extreme physiological stress, surviving desiccation for at least five months (Lysaght, 1941). M. neritoides produces planktonic capsules with a single egg that develops into a freeswimming veliger (Lebour, 1935). Capsules are only released when individuals are submerged. Lysaght (1941) noticed a fortnightly spawning rhythm that coincided with spring tides. On the Irish coast, peaks in maturity and spawning coincided with the period of winter storms (Cronin et al., 2000), especially on less exposed shores. Some authors (Lebour, 1935; Palant and Fishelson, 1968) refer to a seawards mi- gration of females in the spawning season, but this has not yet been conclusively demonstrated by any studies. Planktonic larvae settle on the lower level of rocky shores; the settlement site is not randomly chosen but is based on the favourable conditions of the rocky surface and water column (Newell, 1979; Nybakken, 2000). Juvenile snails remain in the settlement site, feeding on microalgae, until they reach a size of about $1 \mathrm{~mm}$ (shell height). Individuals then start moving upshore, exhibiting negative geotaxis (Fretter and Manly, 1977). This results in a shell size gradient upshore (Lysaght, 1941; Bosh and Moreno, 1986). The population density is higher near the sea due to the presence of juveniles and decreases upshore (Bosh and Moreno, 1986). Growth rate decreases with age, and is very slow in individuals larger than $6.0 \mathrm{~mm}$ (shell height) (Lysaght, 1941).

This study examines the influence of sewage pollution on the population structure and secondary production of Melarhaphe neritoides by providing data on the population dynamics of this species on southern European coasts.

\section{MATERIALS AND METHODS}

\section{Study Site}

The sampling sites were located on the Peniche peninsula (Fig. 1), on the western Portuguese coast. We chose two calcareous shores facing approximately south and with nearly the same exposure and hydrodynamics; one received the effluent of a sewage treatment plant (impacted area) and the other was used as the reference (unimpacted area). The source of stress/pollution is a sewage treatment plant constructed in 1998, which treats effluent to the primary and secondary levels. This plant serves a human population of 40,000 and discharges the effluent directly into the sea.

Three vertical zones which divided the intertidal area into three parts with approximately the same height, were delimitated on each shore: L1 - lower shore, L2 - middle shore, L3 - upper shore.

\section{Sampling}

Monthly samples were collected from April 2004 to July 2005, except in May and August 2004. Samples were collected by placing three quadrats $(15$ $\mathrm{x} 15 \mathrm{~cm}$ ) randomly at each of the three levels (L1, 


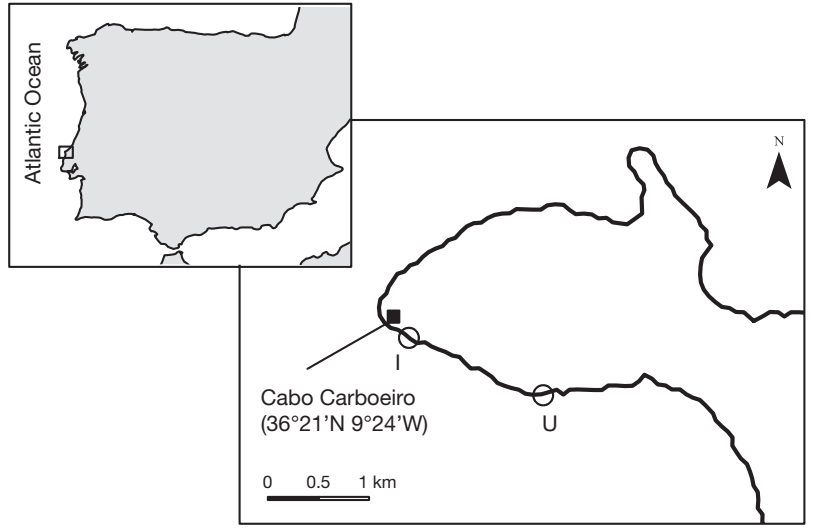

FIG. 1. - Map of Peniche peninsula, western coast of Portugal, showing the location of the sampling stations: I - impacted and U - unimpacted.

L2, L3) on each shore. The number of individuals collected varied from 4 to 925 per quadrat. $\mathrm{pH}$ was measured in situ and water samples were collected for nutrient analyses and chlorophyll $a$ determination. Bacteriological analyses (Enterobacteriaceae, coliforms, Escherichia coli and Pseudomonas) were performed only once: in March 2005.

Since the two sampling stations were close (1.5 $\mathrm{km}$ apart) and had the same orientation and wave exposition, it was assumed that the environmental variables would be similar in the two areas. The nearby (250 $\mathrm{m}$ from the impacted area) weather station of Cabo Carvoeiro provided the monthly precipitation and atmospheric temperature data. Seawater temperature data were obtained in the area of the port of Peniche (500 $\mathrm{m}$ from the unimpacted area).

\section{Laboratory procedures}

All individuals were counted and measured (maximum shell height). A total of 26,096 individuals were examined. Biomass was estimated as ash free dry weight (AFDW): individuals were dried at $60^{\circ} \mathrm{C}$ for four days, weighted, ignited in a muffle furnace at $450^{\circ} \mathrm{C}$ for eight hours, and reweighed to determine the ash content. These determinations were made using the entire animals including the shell.

Water samples were filtered (Whatman GF/F glass-fibre filter) and stored frozen at $-18^{\circ} \mathrm{C}$ until analysis. Analyses followed the standard methods described in Limnologisk Metodik (1985) for ammonia $\left(\mathrm{NH}_{3}-\mathrm{N}\right)$ and phosphate $\left(\mathrm{PO}_{4}-\mathrm{P}\right)$ and in Strickland and Parsons (1968) for nitrate $\left(\mathrm{NO}_{3}-\mathrm{N}\right)$ and nitrite $\left(\mathrm{NO}_{2}-\mathrm{N}\right)$. To determine chlorophyll $a$ content, water samples were filtered and processed following the protocol of Strickland and Parsons (1968).

\section{Data analysis}

In order to study the presence of cohorts and growth rates we used the ANAMOD software package (Nogueira, 1992), that was tested using the $\chi^{2}$ and $G$ tests $(\mathrm{P}=0.05)$. It was not possible to recognize cohorts or estimate growth rates.

Mean population density (individuals $\mathrm{m}^{-2}$ ) and biomass $\left(\mathrm{g} \mathrm{m}^{-2}\right)$ were estimated for sampling area and for shore level. Biomass was estimated according to the conversion equation, biomass $=0.00001 \mathrm{x}$ (shell height) ${ }^{3.3993}\left(\mathrm{R}^{2}=0.9855 ; \mathrm{N}=143\right)$, obtained in this study. To obtain this linear regression we measured and estimated biomass in about 140 individuals from all size ranges, and determined the lengthweight relationships. Differences in density between the impacted and unimpacted areas were analyzed using t-tests and between sampling levels in the two areas using multiple comparisons (all combinations between areas - impacted and unimpacted - and sampling levels - L1, L2 and L3) with SPSS for Windows 15.0. Annual average secondary production was calculated using the size-frequency method by Hynes as modified by Benke (1979)

$$
P=a\left[\sum_{j-1}^{a-1}\left(\bar{N}_{j}-\bar{N}_{j+1}\right) \times \sqrt{\left(\bar{W}_{j} \times \bar{W}_{j+1}\right)}\right] \cdot \frac{365}{C P I}
$$

where $\overline{\mathrm{N}}_{\mathrm{j}}$ is the mean density in size class $\mathrm{j}$ (ind $\mathrm{m}^{-2}$ ), $\overline{\mathrm{W}}_{\mathrm{j}}$ the mean individual weight in size class $\mathrm{j}$ (mg AFDW), CPI the cohort production interval, i.e. mean length of life (days), and $\mathrm{j}$ and $\mathrm{j}+1$ the consecutive size classes $(j=1,2, \ldots, a)$. We considered the life time of $M$. neritoides to be between 5 and 7 years (Lysaght, 1941).

A Redundancy Analysis (RDA) was used to evaluate the effect of the environmental parameters on the abundance and biomass of $M$. neritoides in the different sampling areas and on the different sampling dates. Computations were performed using CANOCO 4.5.

\section{RESULTS}

\section{Environmental data}

At Peniche, the lowest values of mean atmospheric temperature and seawater temperature were recorded in winter (February 2005) and maxima were recorded in summer (August 2004). Maximum 
TABLE 1. - Ranges of atmospheric and seawater temperatures and precipitation during the study period.

\begin{tabular}{|c|c|c|c|}
\hline & Min & $\operatorname{Max}$ & Average \pm SD \\
\hline Atmospheric temp. $\left({ }^{\circ} \mathrm{C}\right)$ & 9.14 & 24.04 & $16.07 \pm 3.39$ \\
\hline Seawater temp. $\left({ }^{\circ} \mathrm{C}\right)$ & 13.00 & 19.10 & $15.01 \pm 1.33$ \\
\hline Precipitation (mm) & 0 & 689 & \\
\hline
\end{tabular}

precipitation was recorded in October 2004 (689 $\mathrm{mm}$ ) (Table 1).

We measured the concentrations of nutrients, bacteria and chlorophyll $a$ in the impacted and unimpacted areas. The highest concentrations of nutrients were generally found in the impacted area (Fig. 2). However, peaks were detected at both sites. Peaks were more pronounced in the impacted area (about 6x the mean concentration) but were also found in the unimpacted area (about $3 \mathrm{x}$ the mean
TABLE 2. - Bacteriological analyses in the two sampling areas.

\begin{tabular}{lcc}
\hline & Unimpacted & Impacted \\
\hline Enterobacteriaceae $(\mathrm{cfu} / \mathrm{mL})$ & 0.06 & 31.6 \\
Coliforms $(\mathrm{cfu} / \mathrm{mL})$ & 0.075 & 89 \\
E. coli $(\mathrm{cfu} / \mathrm{mL})$ & 0.375 & $>300$ \\
Pseudomonas $(\mathrm{cfu} / \mathrm{mL})$ & 0.8 & 135 \\
\hline
\end{tabular}

concentration). We observed peaks in both areas for all nutrients in June 2004; in the impacted area peaks in ammonia, phosphate and silica concentrations occurred in September 2004 and a nitrite peak in February 2005. Values of chlorophyll $a$ were always higher at the unimpacted area, except in March 2005 (Fig. 2). Bacteriological analyses detected higher values for Enterobacteriaceae, coliforms, E. coli and Pseudomonas at the impacted area (Table 2).
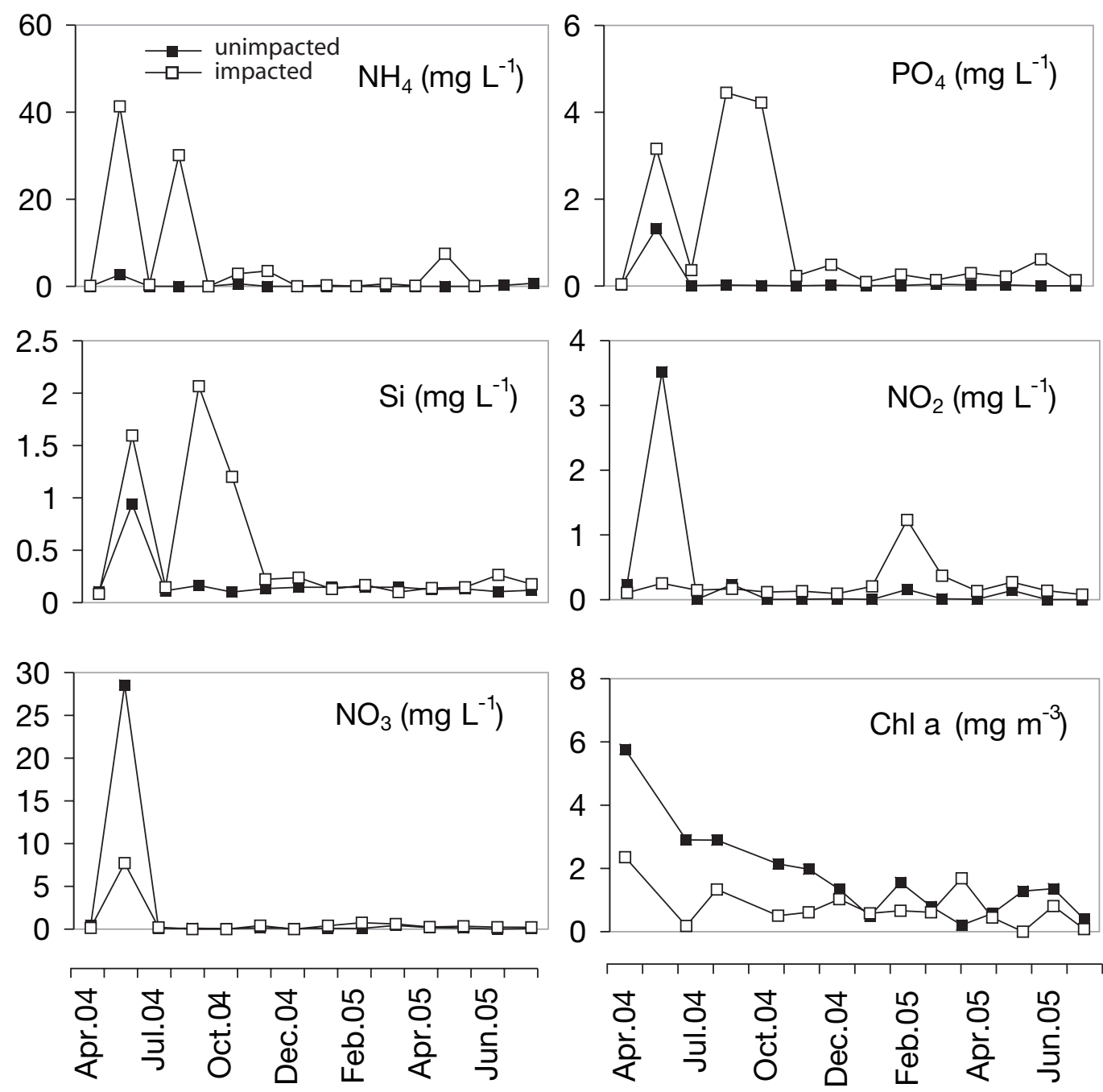

FIG. 2. - Variation of environmental parameters $\left(\mathrm{NO}_{3}{ }^{-}-\right.$nitrate; $\mathrm{NO}_{2}{ }^{-}-$nitrite; $\mathrm{NH}_{4}{ }^{+}-$ammonia; $\mathrm{PO}_{4}{ }^{3-}-$ phosphate; $\mathrm{Si}-$ silica; Chl $a-$ chlorophyll $a$ ) during the study period, in the two sampling areas: unimpacted and impacted. 


\section{Melarhaphe neritoides abundance and distribution}

Population density was higher at the impacted area during the entire 16 months of the study (Fig. 3). Density at sampling levels L2 and L3 was similar in the two areas (Fig. 3) with the major differences occurring at L1. Population density was significantly different between the impacted and unimpacted area (t-test; $\mathrm{t}_{95}=4.05 ; \mathrm{p}<0.05$ ). Multiple comparisons (Tuckey's test; $\mathrm{p}<0.05$ ) between sampling levels at the two areas confirmed that the main difference was due to L1.

Biomass (Fig. 3) in the two areas increased in spring and summer and decreased in autumn and winter. Comparing biomass according to sampling levels in the two areas (Fig. 3) showed higher values for L1 at the impacted area, and higher values for L3 at the unimpacted area.

An RDA analysis was carried out in order to evaluate the effect of the environmental parameters on the abundance of $M$. neritoides (Fig. 4). The first
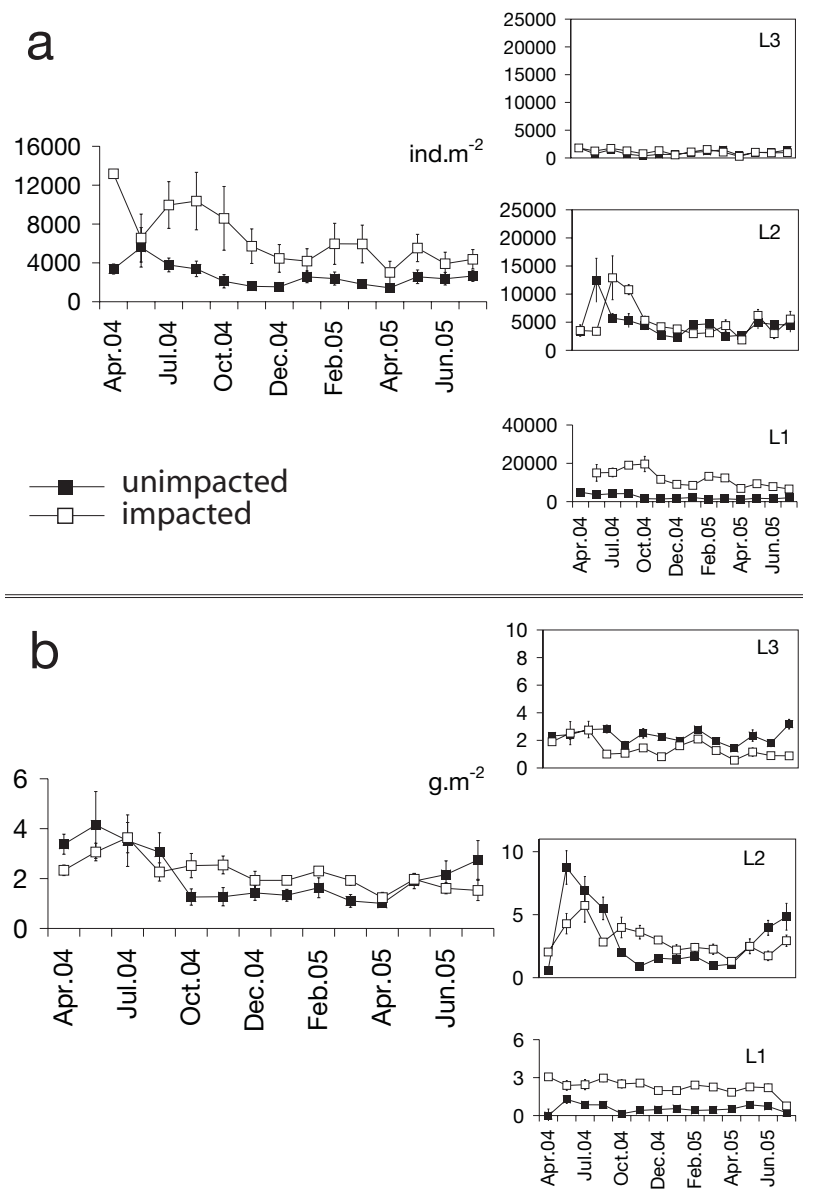

FIG. 3. - a. Density (ind $\left.\mathrm{m}^{-2}\right)$ and b. biomass $\left(\mathrm{g} \mathrm{m}^{-2}\right)$ during the 16 months of the study, according to sampling area (unimpacted and impacted) and level (L1, L2 and L3).

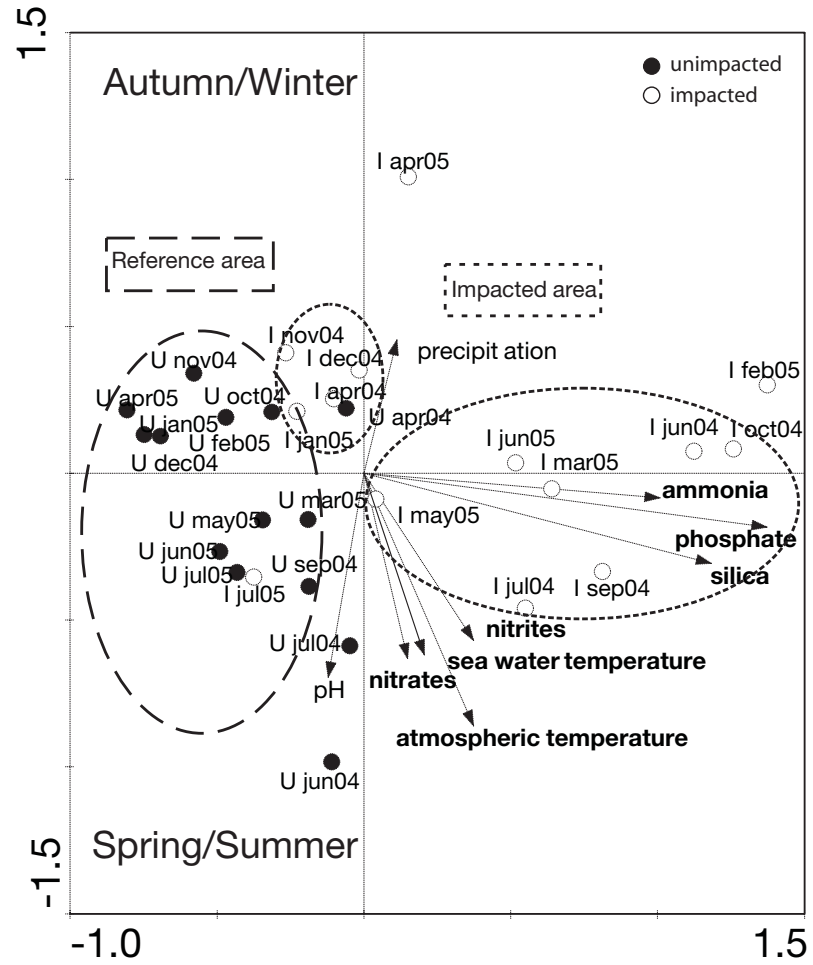

FIG. 4. - Ordination diagram for the two canonical axes of the Redundancy Analysis performed using Melarhaphe neritoides density and biomass values. Sampling areas: $\mathrm{U}$, unimpacted and I, impacted.

axis explained $62.2 \%$ of the variance and the second axis explained $25.9 \%$. The ordination detected spatial differences between the two areas: unimpacted samples were located on the left side of the ordination diagram and impacted samples on the right. Temporal differences were also detected: the spring and summer samples were located in the lower quadrants while the autumn and winter samples were located in the upper quadrants.

\section{Population structure and production}

Seasonal variation in the size-frequency distributions of $M$. neritoides from the impacted and unimpacted area at each level is shown in Figure 5. The largest individuals collected from the unimpacted area measured $8.41 \mathrm{~mm}$ while those from the impacted area measured $6.57 \mathrm{~mm}$. The smallest individuals measured $0.59 \mathrm{~mm}$ in both areas. In both areas the size of individuals tended to increase from the lower shore level (L1) to the higher one (L3). In the impacted area the number of individuals decreased upshore but in the unimpacted area the number of individuals was higher at L2 followed by L1 and then L3.

A comparison of the population structures in the two sampling areas (Fig. 6) showed that smaller individuals 
Unimpacted
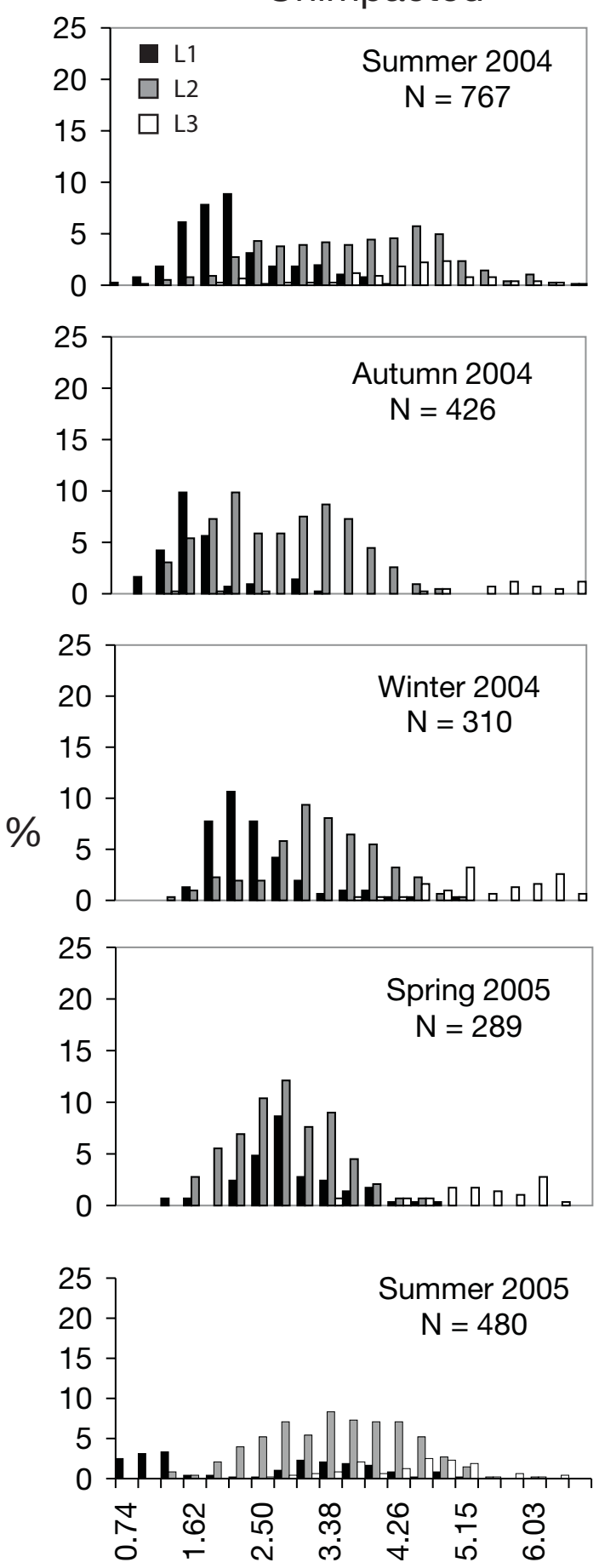

Impacted
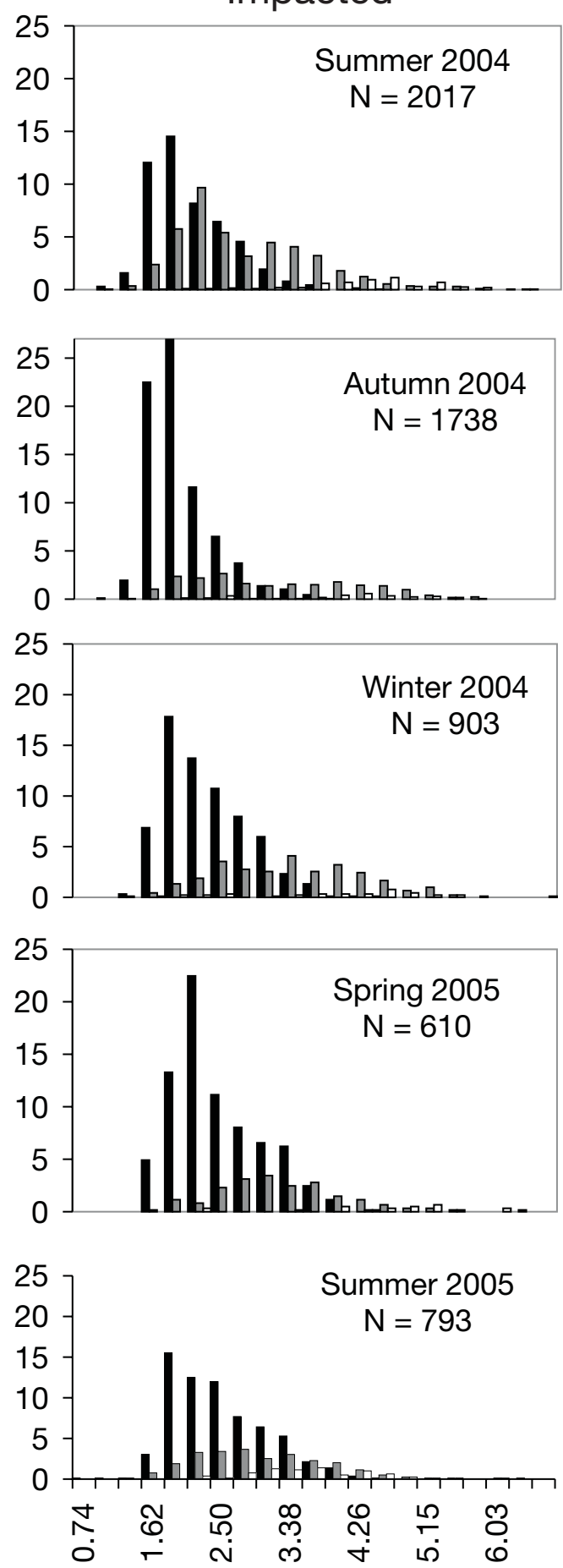

Shell length

FIG. 5. - Population structure of Melarhaphe neritoides according to levels (L1, L2, L3) on the two shores (unimpacted and impacted) during the months April 2004 to July 2005.

were more abundant in the impacted area and larger snails were more abundant in the unimpacted area. At both areas it was impossible to distinguish cohorts (using ANAMOD software package). Therefore, the population was assumed to have continuous reproduction throughout the year. Nevertheless, a reproduction pulse was observed in June/September, and was more evident in 2005 than in 2004 and in the unimpacted area.

The estimated annual production ranged from 1.7 $\mathrm{g} \mathrm{m}^{-2}$ year ${ }^{-1}$ (in the unimpacted area) to $2.2 \mathrm{~g} \mathrm{~m}^{-2}$ 

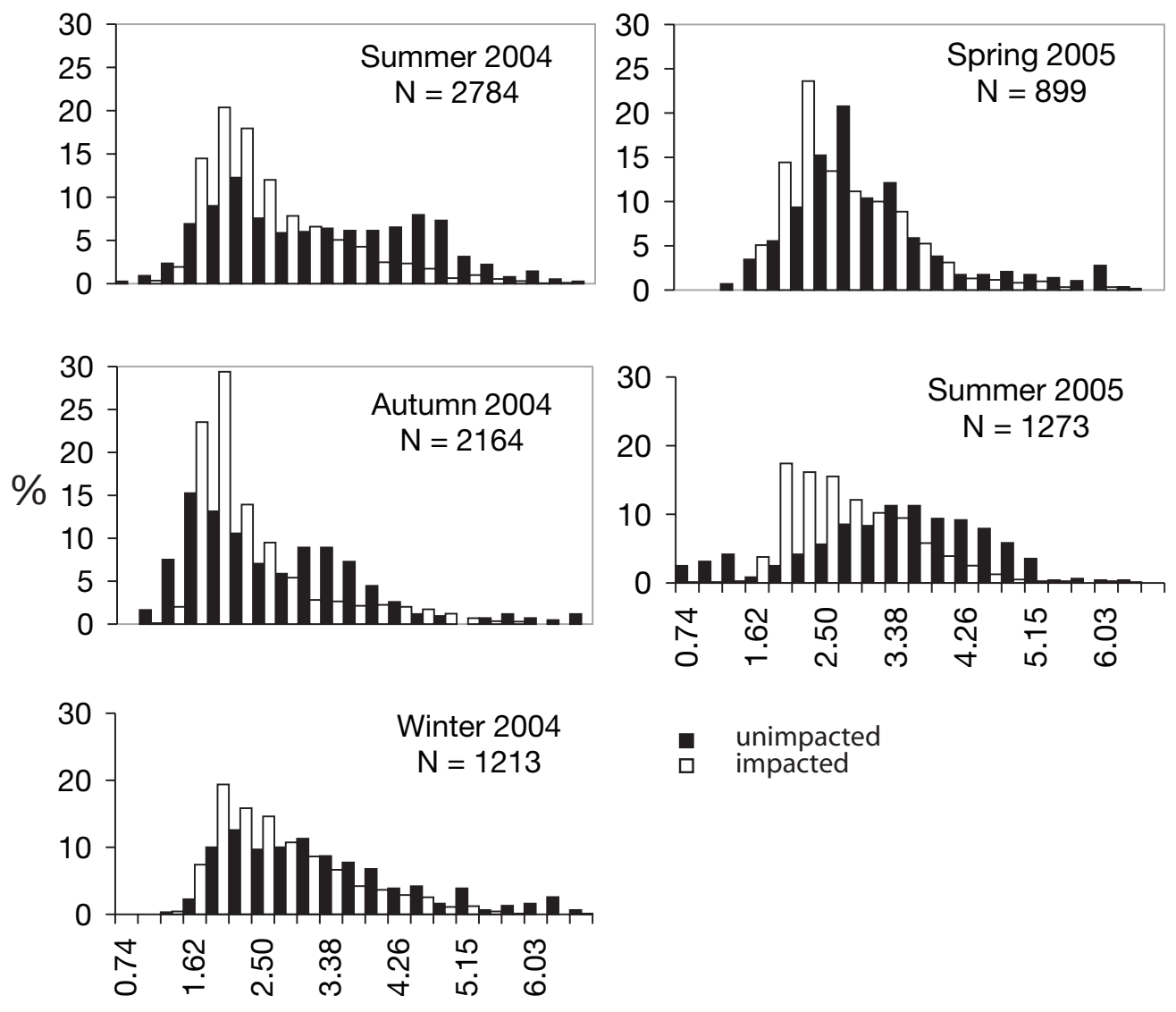

\section{Shell lenght $(\mathrm{mm})$}

FIG. 6. - Seasonal differences in the population structure of Melarhaphe neritoides, on both shores (unimpacted and impacted).

year $^{-1}$ (in the impacted area). Production/Biomass ratios ranged from 0.9 (in the unimpacted area) to 1.1 (in the impacted area).

\section{DISCUSSION}

\section{Environmental Data}

The discharges from the sewage treatment plant increased the nutrient concentrations and the amount of bacteria in the seawater at the impacted area. The peaks observed in nutrient concentrations occurred, most probably, when the sampling dates coincided with a discharge from the sewage treatment plant. Nevertheless, chlorophyll $a$ was higher at the unimpacted area. Due to the discharges of the wastewater treatment plant, the turbidity of the seawater was higher at the impacted area, which may explain the lower amount of phytoplankton. Competition between the bacteria and the phytoplankton in the impacted area is another possible explanation for the lower values of chlorophyll $a$ in that area (BacelarNicolau et al., 2003).

\section{Melarhaphe neritoides abundance and distribution}

Population density was higher at the impacted area. The main difference occurred at L1 and may be related to the fact that juveniles recruit on the rocky shore at this level. Two aspects of $M$. neritoides larval biology affect the population structure on the rocky shore. First, larvae survival in the plankton (since larvae need to find enough food resources, maintain their position in the water column and avoid predators); second, the larvae must settle and metamorphose into adults (Little and Kitching 1996). According to Newell (1979) and Nybakken (2000) settlement sites are not chosen randomly but rather larvae are influenced by the physico-chemical properties of the rocky shore (presence of crevices) and water column (light, salinity) and by the presence of certain species. 
The higher concentration of nutrients at the impacted area may be the cause of a larger quantity of microalgae, on which $M$. neritoides feed, on the rocky surfaces. This could be attractive to settling $M$. neritoides larvae, and explain the higher densities at L1 at the impacted area.

Despite the significant difference at L1, densities at L2 and L3 were not statistically different in the two areas. This might reflect considerably high mortality at L1 at the impacted area, as a large settlement would increase intraspecific competition for food and space (Chen and Richardson, 1987), which could lead to high mortality.

M. neritoides biomass was higher in spring/summer. Since this gastropod feeds on microalgae present on the rocky shore, the biomass of the snail could follow the seasonal pattern of abundance of microalgae. Therefore, this seasonal biomass variation may be related to food availability. This pattern was not so accentuated at the impacted area as the higher concentration of nutrients increased the availability of phytobenthos all year around. A comparison of biomass according to sampling level in the two areas showed higher values for L1 at the impacted area, which can be explained by the higher number of juveniles. The unimpacted area had higher biomass values at L3 despite the similar densities when compared to the impacted area. This is confirmed by the presence of larger animals (due to a higher growth rate or longer life span) at the unimpacted area.

The multivariate analysis clearly showed that the discharges of the sewage treatment plant increase the amount of ammonia, phosphate and silica in the seawater, which conditions the population structure and abundance of $M$. neritoides. Nitrates and nitrites along with the other environmental variables are correlated with the sampling dates: precipitation was correlated with autumn/winter; seawater temperature and atmospheric temperature were correlated with spring/summer; nitrates and nitrites were correlated with spring/summer.

\section{Population structure and production}

Shell size increased upshore in both study areas because snails move up the shore as they grow larger (Fretter and Manly, 1977). At the impacted area the highest densities were found at L1 due to the large settlement. At the unimpacted area the highest densities were found at L2. This could be due to the fact that there was no significant settlement event at this site, and as L1 is more subjected to wave action $M$. neritoides may occupy this level only until they are able to move upshore. In both impacted and unimpacted areas, L3 always had the lowest abundance. Although the abundances at L3 were similar for both areas, we found smaller individuals at the impacted area, which suggests that individuals had shorter life spans or lower growth rates.

In this study $M$. neritoides showed continuous recruitment throughout the year, with a pulse in June/ September. This was expected. since other studies in northern latitudes (Fretter and Manly, 1977; Fretter and Graham, 1980) observed continuous recruitment with two pulses in March/April and September/October. The present study was conducted in southern latitudes with a temperate climate. The reproduction peaks may be less accentuated in our study because an increase in temperature is not as important for reproduction as in northern latitudes.

Annual growth production was higher at the impacted area, which could be explained by the larger number of juveniles. The large settlement event is also reflected in the higher $\mathrm{P} / \mathrm{B}$ ratio at the impacted area, which reflects higher turnover rates.

Overall, the discharge from the sewage treatment plant increased the nutrient concentration in the seawater at the impacted area. The presence of higher amounts of nutrients may have led to better development of phytobenthos, on which Melarhaphe neritoides feeds, on the rocky surfaces compared to the unimpacted site. This would in turn make the impacted area more attractive to $M$. neritoides for recruitment. Despite the considerable number of juveniles, a significant mortality in $\mathrm{L} 1$ at the impacted area leads to similar density values at L2 and L3 in the two areas. Moreover, the reference area has larger individuals at L3 compared with those at the impacted area, which is possibly due to longer life spans or higher growth rates. In our work, which did not replicate control sites, differences in population structure and secondary production of $M$. neritoides cannot be unambiguously attributed to the presence of the sewage effluent. However, we consider that our results indicate that the effluents modified the population dynamics of $M$. neritoides.

\section{ACKNOWLEDGEMENTS}

We sincerely thank Susana Mendes for all her help with the statistical analyses. We wish to thank 
the two anonymous reviewers for their kind and helpful contributions.

\section{REFERENCES}

Arévalo, R., S. Pinedo and E. Ballesteros. - 2007. Changes in the composition and structure of Mediterranean rocky-shore communities following a gradient of nutrient enrichment: Descriptive study and test of proposed methods to assess water quality regarding macroalgae. Mar. Pollut. Bull., 55: 104-113.

Bacelar-Nicolau, P., L.B. Nicolau, J.C. Marques, F. Morgado, R. Pastorinho and U.M. Azeiteiro. - 2003. Bacterioplankton dynamics in the Mondego estuary (Portugal). Acta Oecol., 24 S67-S75.

Benke, A.C. - 1979. A modification of the Hynes method for estimating secondary production with particular significance for multivoltine populations. Limnol. Oceanogr., 24(1): 168-171.

Bishop, M.J., A.J. Underwood and P. Archambault. - 2002. Sewage and environmental impacts on rocky shores: necessity of identifying relevant spatial scales. Mar. Ecol. Prog. Ser., 236: 121-128.

Bosh, M. and I. Moreno. - 1986. Spatial distribution of Littorina neritoides (L. 1758) (Mollusca, Gastropoda) in the supralitoral zone in the Balearic Islands. Cah. Biol. Mar., 42: 53-62.

Chen, Y.S. and A.M.M. Richardson. - 1987. Factors affecting the size structure of two populations of the intertidal periwinkle Nodilittorina unifasciata (Gray, 1839) in the Derwent River, Tasmania. J. Molluscan Stud., 53: 69-78.

Cronin, M.A., A.A. Myers and R.M. O'Riordan. - 2000. The reproductive cycle of the intertidal gastropod Melarhaphe neritoides on the west and south coasts of Ireland. In: Bruce Osborne (ed.), Environ. Proc. R. Ir. Acad., 100B(2): 97-106. Dublin, Ireland.

Ferskvandsbiologisk Laboratorium - 1985. Limnologisk Metodik. Kobenhawns Universitet (ed.), Akademisk Forlag, København.

Fraschetti, S., C. Gambi, A, Giangrande, L. Musco, A. Terlizzi and R. Danovaro. - 2006. Structural and functional response of meiofauna rocky assemblages to sewage pollution. Mar. Pollut. Bull., 52: 540-548.

Fretter, V. and A. Graham. - 1980. The prosobranch molluscs of Britain and Denmark. Part 5 - Marine Littorinacea. J. Molluscan Stud., 7: 243-284.

Fretter, V. and R. Manly. - 1977. Settlement and early benthic life of Melarhaphe neritoides (L) at Wembury, S Devon. J. Mol- luscan Stud. 43: 255-262.

Gappa, J.L., A. Tablado and N.H. Magaldi. - 1990. Influence of sewage pollution on a rocky intertidal community dominated by the mytilid Brachidontes rodriguezi. Mar. Ecol. Prog. Ser., 63: 163-175.

Hughes, R.N. and D.J. Roberts. - 1981. Comparative demography of Littorina rudis, L. nigrolineata and $L$. neritoides on three contrasted shores in North Wales. J. Anim. Ecol., 50: 251-268.

Lebour, M.V. - 1935. The breeding of Littorina neritoides. J. Mar. Biol. Ass. U.K., 20: 373-378.

Little, C. and J.A. Kitching. - 1996. The biology of rocky shores. Oxford University Press, New York.

Lysaght, A. - 1941. The biology and trematode parasites of the gastropod Littorina neritoides (L.) on the Plymouth Breakwater. $J$. Mar. Biol. Ass. U.K., 25: 41-67.

Newell, R.C. - 1979. Biology of intertidal animals. Marine Ecological Surveys, Ltd. Faversham.

Nogueira, A.J. - 1992. ANAMOD - Extraccão dos componentes modais de distribuições de frequências de variáveis biométricas. Provas de aptidão pedagógica e capacidade científica. University of Coimbra, Coimbra.

Nybakken, J.W. - 2000. Marine Biology: An Ecological Approach. Benjamin Cummings. USA.

Palant, B. and L. Fishelson. - 1968. Littorina punctata and M. neritoides from Israel: ecology and annual cycle of the genital system. Isr. J. Zool., 17: 145-60.

Raffaelli, D.G. and R.N. Hughes. - 1978. The effect of crevice size and availability on populations of Littorina rudis and Littorina neritoides. J. Anim. Ecol., 47: 71-83.

Stafford R. and M.S. Davies. - 2005. Examining refuge location mechanisms in intertidal snails using artificial life simulation techniques. In: M. Capcarrere et al. (eds.), Lecture Notes in Artificial Intelligence. Proc. VIIIth Eur. Conf. Art. Life, 3630: 520-529. Springer Berlin, Heidelberg.

Strickland, J.D.H. and T.R. Parsons. - 1968. A practical handbook of seawater analysis. Bull. Fish Res. Board Can., 167: 1-311.

Tablado, A. and J.L. Gappa - 2001. Morphometric diversity of the pulmonate limpet Siphonaria lessoni in different coastal environments. Sci. Mar., 65(1): 33-41.

Terlizzi A., D. Scuderi, S. Fraschetti and M.J. Anderson. - 2005. Quantifying effects of pollution on biodiversity: a case study of highly diverse molluscan assemblages in the Mediterranean. Mar. Biol., 148: 293-305.

Scient. ed.: Álvarez Salgado.

Received November 19, 2007. Accepted September 9, 2008.

Published online March 2, 2009. 